\title{
Challenges and opportunities fOr KOREAN Missionaries IN SOUTHERn Africa
}

\author{
Authors: \\ Kyung $\mathrm{H} . \mathrm{Oh}^{1}$ \\ Piet G.J. Meiring ${ }^{1}$
}

\section{Affiliations: \\ ${ }^{1}$ Department of Science of Religion and Missiology, University of Pretoria, South Africa}

\section{Correspondence to:}

Kyung H. Oh

e-mail:

khohsim@gmail.com

\section{Postal address:}

University of Pretoria, PO Box 76234, Lynnwood Ridge, 0040, South Africa

\section{Keywords:}

Korean missionaries; missionaries in Southern Africa; missiology; history of missions in Korea; missionary Church

\section{Dates:}

Received: 17 June 2008

Accepted: 19 Mar. 2009

Published: 04 May 2009

How to cite this article: Oh, K.H. \& Meiring, P.G.J., 2009, 'Challenges and opportunities for Korean missionaries in Southern Africa', HTS Teologiese Studies/Theological Studies 65(1), Art. \#153, 6 pages. DOI: 10.4102/hts.v65i1.153

\section{This article is available} at: http://www.hts.org.za

\section{Note:}

This article is based on the Rev. Dr K.H. Oh's PhD dissertation, entitled 'Korean missionaries in Southern Africa, 1980-2006', accepted in the Department of Science of Religion and Missiology at the Faculty of Theology, University of Pretoria, South Africa, under the supervision of Prof. Dr P.G.J. Meiring.

\section{(c) 2009. The Authors.} Licensee: OpenJournals Publishing. This work is licensed under the Creative Commons Attribution License.

\section{ABSTRACT}

This article describes the history of missions in Korea as well as the challenges and opportunities for Korean missionaries in Southern Africa. The most significant problems encountered by Korean missionaries include understanding local context, language and culture acquisition, and meeting the expectations of local people and local churches as well as those of sending churches in Korea. On a personal level, missionaries have to cope with family concerns, maintaining their spiritual life, health problems, financial concerns, frustrations and unfulfilled ideals. Korean missionaries in Southern Africa do, however, have a unique opportunity to serve the Church in its mission and, above all, to serve the Lord of the Church in his mission, although there are indeed difficulties to overcome and challenges to face.

\section{INTRODUCTION}

\section{From mission field to missionary church}

Korea's evangelisation was planned by God's providential work. Jesus said, 'As the Father has sent me, I am sending you' (Jn 20:21). Before Jesus ascended into the heavens, he gave this instruction to his disciples:

Do not leave Jerusalem, but wait for the gift my father promised, in a few days you will be baptized with the Holy Spirit ... But you will receive power when the Holy Spirit comes on you, and you will be my witnesses in Jerusalem, and in all Judea and Samaria, and to the ends of the earth.

(Ac $1: 4,5,8)$

Jesus explained to his followers that their mission fields included all tribes and nations. When the disciples received the Holy Spirit at Pentecost, they became his witnesses. The church at Antioch served as a base for the mission to Gentiles. As Neill (1965) and Tucker (1983) have pointed out, the gospel spread throughout the Roman world, European countries, North America, Latin America, Asia and Africa through the working of the Holy Spirit and its inspired missionaries.

Korea was initially a mission field. Over the past century, many Western mission agencies and missionaries worked to evangelise Korea. From the beginning of Christianity in Korea, Koreans became involved in evangelism, Bible translation and church planting ministry in collaboration with missionaries.

The turning point of the mission movement of the Korean Church occurred during the 1980s. The Korean Church quickly changed from being a mission field to a significant sending field because Korean churches were growing robustly, ${ }^{1}$ the economy of Korea was developing, ${ }^{2}$ the political situation was changing and the second revival was taking place. Furthermore, increasing numbers of Korean people were immigrating to countries all over the world. The government was also changing its policy with regard to travel. ${ }^{3}$ During this time, the evangelical movement influenced Korean Christians to become involved in world missions, ${ }^{4}$ while 'Mission Korea' challenged young Christians. ${ }^{5}$ Moon (2007:1), Director of the Korean Mission Research Institute, has stated that 'the Korean churches sent 2576 missionaries in 1992. There were 14905 Korean missionaries and 174 Mission Agencies in Korea in 2006.'

The development of Korean churches to the position of sending missionaries is the fruit not only of the ministry of Western missions but also of Korean churches and mission leaders. Western mission agencies and missionaries opened the door to Korean churches to share in their rich experience of world missions; Korean churches and leaders, in their turn, welcomed this and became deeply involved in the process. This poses another challenge for Korean missionaries who are serving in the mission field: to serve local people and enter into a partnership with younger indigenous churches for the purpose of fulfilling the Great Commission.

As mentioned, Korea has changed from a mission field to a sending field. A special feature of the Korean mission movement is that it involves not only different denominations but also unrelated individual mission agencies. This is a result of the passionate commitment of Korean pastors, mission leaders

1.In 1973 , there were 7300 churches and 1650000 members, with the church growing rapidly to 30000 churches and 11000000 members in 1989

2.Development in the Korean economy meant that Korean church funds increased. Because Korean churches were growing during this period, sending churches were able to start supporting missionaries.

3.The Korean government controlled Korean travellers very strictly until 1990.

4.Expo '74, the Billy Graham Mass Evangelism Movement, the ' 77 National Evangelism Movement and the ' 80 World Evangelical Movement challenged Korean Christians to world missions. During the conference concerned, many Christians dedicated themselves to mission work.

5.'Mission Korea' is a large biennial nation-wide mission conference of various youth agencies (IVF, JOY, CCC, Navigators etc.). Thousand of young people have been recruited for short-term involvement by YWAM, CCC, OM and others. 
and church members. The Korean Church, however, still has the task of developing the leadership of Korean missions as well as effective mission strategies and policies for the mature missionary movement of today.

Over 250 Korean missionaries have committed themselves to the Great Commission of the Lord, having been involved in various ministries in Southern Africa since 1980. They face a number of challenges and opportunities in the mission field. Four of these challenges can be outlined as follows:

Firstly, one of the main challenges facing the Church in Southern Africa is that of shallow spirituality and faith. According to Johnstone and Mandryk (2001), of the total population in each country in Southern Africa, 73.52\% in South Africa, 79.98\% in Malawi, $66.89 \%$ in Botswana, $71.85 \%$ in Lesotho, $82.70 \%$ in Swaziland, $71.71 \%$ in Zimbabwe, $85.04 \%$ in Zambia, $79.95 \%$ in Namibia and 57.65\% in Mozambique are Christian. According to these statistics, the countries concerned appear to be Christian in nature. But vexing questions remain: how deep is the commitment of the Christians to their Lord and how do they live their faith in everyday life? And do they influence and transform their communities? There are serious problems of crime, violence and poverty in South Africa in particular. To my mind, these social situations are closely related to the standard of spirituality in South Africa; there is a desperate need for a great awakening in Southern African countries.

The second challenge in Southern Africa relates to churchleadership problems. The African Church displays weak leadership, especially in its modes of training and development (Taylor 1997:280). The training of church leaders is an urgent priority in Mozambique, for example. The training of Christian leaders is, however, a multi-faceted challenge and, although much is being done, a great deal of room for improvement remains (Johnstone \& Mandryk 2001:458, 579).

Thirdly, the challenges in Southern Africa fall within the realm of socio-economic and political problems. The euphoria of the 'New' South Africa has worn off: There are too many African examples of demagoguery, decline, corruption and cronyism for there to be any complacency; the legacy of contempt, mistrust, fear, injustice, violence, intimidation and deep hurt has scarred the soul of the nation. The escalating crime wave has shocked the country; the major growth industry is security because violent robbery, car hijacking and rape have become commonplace. The country furthermore reports a murder rate over seven times that of the USA and few crimes result in convictions. South Africa has become a pluralist society and Christians are no longer tied to its power structures, which makes it difficult for church leaders to play a prophetic or a priestly role and help contain the situation (Johnstone \& Mandryk 2001:578-579). On the other hand, the situation in South Africa offers huge challenges not only to missionaries but to all Christians in South Africa.

The fourth challenge concerns African culture: how to present the gospel of Jesus Christ through 'clothing' it in the culture of Africa but without compromising the content and truth of the message. The proliferation of African Independent Churches in South Africa in recent times is a constant reminder of the necessity for the Christian mission to take the issue of culture very seriously.

\section{UNDERSTANDING THE CONTEXT}

Each mission field is characterised by a unique context, where the process of development in the history and culture of each field is evident. As newcomers, Korean missionaries must observe this context carefully. If they ignore it, they will not achieve the ministry goal in the host country. Most Korean missionaries have grown up in a monolingual culture. They therefore need to learn as much as they can about the context of the host country before they arrive and must continue to learn in this regard while they are there. In this light, Korean mission agencies should suggest that their missionaries study the context for an extensive period before they begin their ministry in the field.

In this article, I describe the research results stemming from the questionnaires that I administered among Korean missionaries.

I contacted them on three different occasions between 4 July 2006 and 31 March 2007. On the first occasion, I gave the questionnaires to Korean missionaries when I attended a conference of the Korean Missionary Fellowship in Central and Southern Africa from 4 to 7 July 2006 at the Wigwam Hotel in Rustenburg; 35 questionnaires were returned. The second time, I distributed questionnaires via email to all Korean missionaries working in Southern Africa; six people responded. On the third occasion, I personally contacted Korean missionaries living in Pretoria and Potchefstroom; eight completed questionnaires were returned.

This article deals with the questionnaires that I used and the responses that I received.

TABLE 1

Understanding the context

\begin{tabular}{lrrr}
\hline & $\begin{array}{r}\text { UNDERSTANDING } \\
\text { POSITIVELY }\end{array}$ & $\begin{array}{r}\text { LESS } \\
\text { UNDERSTANDING }\end{array}$ & NO ANSWER \\
\hline Numbers & 30 & 6 & 13 \\
Percentage & $61.22 \%$ & $12.24 \%$ & $26.53 \%$ \\
\hline
\end{tabular}

\section{Understanding the local context}

How do the Korean missionaries understand the context? Typical answers received were as follows:

- 'I thought I understood the culture, but as I worked among the local people, I encountered new difficulties concerning traditional culture.'

- 'The longer I live on [sic] the field, the more I am getting to understand the culture.'

- 'I have had no difficulties in adapting to the culture and the context because I have had experience in other mission fields.'

- 'I did research for a year before I began my ministry.

- 'I had a difficult time at first because I did not understand the culture very well. I am adjusting to it as I am living and working in the field.

- 'In the beginning, I started my ministry with a passion and a commitment to the great commission rather than having an understanding of the context, so I made many mistakes in my ministries.

- 'Even though I am different from the people, my attitude is always to learn from them.'

- 'I have learned the word 'patience' on [sic] the mission field. I think that knowing the local people, the history, the geography and the culture is a life-long process on [sic] the mission field.

- 'I have studied the history of Christianity in the country to gain an understanding of its culture.'

- 'I am trying to learn more about the culture.'

As shown above, the Korean missionaries do attempt to adapt to and understand the culture in which they work.

\section{Difficulties faced by Korean missionaries in the local context}

What difficulties do the Korean missionaries encounter in understanding the context? I have summarised and paraphrased the findings of the questionnaire that I obtained from the missionaries who responded:

- 'It is not easy to adapt to the culture.'

- 'I felt that I had adapted to the culture after I studied it but I have not found it easy to adapt to some of the cultures that I 
have encountered during my ministry.'

- 'I have tried to adapt to a culture that has a different concept of time, food and lifestyle but I was disappointed by the lack of commitment of the people.'

- 'It is very difficult to adapt to cultural ways where people do not keep times, promises or schedules.

- 'I found the adjustment to local food very difficult.'

In his book The South African context for mission (1988), Kritzinger has helped us to understand the context in South Africa. Korean missionaries, in particular, should study the context of the country comprehensively; they can use various methods and approaches to do so. In their research, Johnstone and Mandryk (2001) have found that the proportion of the Christian population in South Africa is $73.50 \%$; this finding included all denominations, even independent churches. This means that there is a higher percentage of churchgoers in South Africa than in any other Southern African country. The African Independent Churches are an extraordinary mixture. They endeavour to consolidate their traditional customs with the Word of God to present the gospel of Jesus in the cloak of Africa. This phenomenon offers a challenge to missionaries in this area. The first task for Korean missionaries is therefore to acquaint themselves with the South African scene, the status of churches as well as the most pressing needs of the people.

There is a great need for Bible teaching in the churches of Southern Africa, as mentioned previously. Kritzinger, Meiring and Saayman (1994:113) have stated that the priority in the mission should be evangelism, or socio-economic development, because of the poverty and unhealthy conditions of the specific situation. The mission could find itself in a pioneer situation, or work under the able leadership of indigenous Christians.' There is also a great need to train or retrain pastors and church leaders theologically for the sake of pastoral ministry, counselling, home cell groups, home visiting, discipleship, leadership development, church administration as well as children and youth ministries because most pastors are not sufficiently equipped to carry out their pastoral ministry. HIV / AIDS ministry, in particular, is one of the most desperately needed ministries in Southern Africa.

\section{LANGUAGE AND CULTURE ACQUISITION}

Language is the basic tool of communication among people. Language learning is therefore essential to the whole cultural learning process. Individuals who choose to minister crossculturally but do not learn the language will always be excluded from a deep understanding of local culture. As Lingenfelter (Moreau 2000:254) has said: 'The best time to engage in intentional cultural learning is during the first two years of ministry.' Dick Anderson, who was International General Secretary of the Africa Inland Mission (AIM) (from 1978 to 1990), told a Korean missionary that '[w]ith a dozen Koreans in the mission, AIM saw the importance of adequate preparation before they left their own country. Most missionaries find their greatest challenge in adjusting to African culture, but Koreans in an international society experienced a more painful adjustment than westerners. They thought that colleagues regarded them as 'too Korean' and resented their lack of fluency in English' (Anderson 1994:316). 'Language is a very important symbol of identity for a people and mastering it is a sign of respect' (LloydSidle \& Lewis 2001:42).

\section{Korean missionaries' language learning}

Korean missionaries who operate in various mission fields frequently interpret the customs of the host country from a Korean perspective. The question is one of overcoming this difficulty. These missionaries need to learn two or more languages - usually English and the local language - which is very difficult for them. Most of them studied English grammar at school and learned English while in their 20s and 30s. They must, however, overcome these difficulties for their ministry to be effective and dynamic over a long time.
TABLE 2

Korean missionaries' language leve

\begin{tabular}{lrrrr}
\hline & POOR & GOOD & EXCELLENT & NO ANSWER \\
\hline Numbers & 13 & 30 & 2 & 4 \\
Percentage & $26.53 \%$ & $61.22 \%$ & $4.08 \%$ & $8.16 \%$ \\
\hline
\end{tabular}

International mission agencies do, in fact, require new missionaries to learn English as well as a local language in order to communicate effectively. For instance, Serving in Mission requires new missionaries to study language and culture for at least two years before they actively begin their ministry. The Global Mission Society (GMS) also requires that a local language be studied for at least one year before an active ministry is embarked on. Most Korean missionaries, however, want to begin their ministry as soon as possible. They must nevertheless be able to communicate the gospel understandably in the local language; they must also be able to feel at ease in the host culture (Beals 1985:174-175).

What level of language acquisition do the Korean missionaries possess? Table 2 offers an indication of this.

According to my research, it appears that $61.22 \%$ of Korean missionaries' language acquisition is good: $4.08 \%$ have reached a standard of excellence and $26.53 \%$ are poor; $8.16 \%$ did not reply with regard to their language proficiency.

In the questionnaires, however, I did not draw a distinction between English and a local language. If I had asked more detailed questions, the results might therefore have been different.

\section{Korean missionaries' cultural adaptation}

Many Korean missionaries spend their 20s and early 30s engaged in their own university education, military service, theological education and pre-field missionary training before entering missionary service. This unusually long period of preparation in their home country is disadvantageous in terms of intercultural adjustment, learning and creativity because these qualities are better acquired when one is younger (Moon 2007:1).

Cultural adaptation especially is hard for Koreans, who originate from a monocultural and monolingual nation. How do Korean missionaries understand and adapt to culture?

According to my research, $68.09 \%$ of the Korean missionaries have adapted very well to local culture (see Table 3).

\section{MEETING THE EXPECTATIONS OF LOCAL PEOPLE AND CHURCHES}

Mission strategies should not only be a one-way process in the field. They should also comprise a process of interaction between the missionaries and local people. When missionaries arrive in a new area as strangers and foreigners, their attitude towards people is very important. We can learn many valuable lessons from the history of missions during the time of colonisation - a time when missionaries often failed to understand and address the needs of the people whom they were sent to serve.

Korean missionaries should study the current expectations of local people and churches, especially because they often make mistakes in the field. These mistakes tend to stem from their background: they want to begin their ministry straightaway because they are under pressure to send reports back to their supporters.

TABLE 3

Korean missionaries cultural adaptation

\begin{tabular}{rrrr}
\hline & VERY POSITIVE & DIFFICULT & NO ANSWER \\
\hline Numbers & 32 & 8 & 9
\end{tabular}

\begin{tabular}{llll} 
Percentage & $68.09 \%$ & $16.33 \%$ & $18.37 \%$ \\
\hline
\end{tabular}


TABLE 4

Ministries in which missionaries should be involved

\begin{tabular}{rrrrrr}
\hline & $\begin{array}{r}\text { LEADERSHIPI } \\
\text { DISCIPLESHIP } \\
\text { DEVELOPMENT }\end{array}$ & $\begin{array}{r}\text { CHARITABLE } \\
\text { MINISTRY }\end{array}$ & CHURCH PLANTING & BIBLE SCHOOL & $\begin{array}{r}\text { CHILDREN'S } \\
\text { MINISTRY }\end{array}$ \\
\hline $\mathrm{N}$ & 6 & 5 & 3 & 3 & 3 \\
$\mathrm{P}$ & $31.57 \%$ & $26.31 \%$ & $15.78 \%$ & $15.78 \%$ & $15.78 \%$ \\
\hline
\end{tabular}

When I conducted my research, I asked the African pastors and leaders of the Africa Evangelical Church (AEC) in the Pretoria circuit in Rustenburg, Soshanguve, Zithobeni and Limpopo several questions between 15 July and 30 October 2006. I obtained 19 answers, as can be seen in Tables 4 and 5 .

\section{Ministries in which missionaries should be involved}

Local people expect the Korean missionaries to be involved in the following areas of ministry: $31.57 \%$ expect leadership or discipleship development; $26.31 \%$ prefer a charitable ministry; $15.78 \%$ feel the need for church planting, Bible school and children's ministry; and $10.52 \%$ are in favour of youth ministry.

\section{Ministries in which missionaries should not be involved}

According to my research, $26.31 \%$ of local people prefer charitable ministry to other ministries. But, in an interview on 15 August 2006, Mohau Mofokeng, a pastor at AEC, suggested that '[c]hurch planting is unnecessary because there are many Christian churches already in our region'. In the eyes of local pastors and leaders especially, the Korean missionaries are newcomers. These leaders do not yet fully understand who the Korean missionaries are, what they want and how to build relationships with them. This is why $57.89 \%$ of local people responded with 'No answer' (see Table 5).

\section{MEETING THE EXPECTATIONS OF SENDING CHURCHES IN KOREA}

In his book The church is bigger than you think, Johnstone (1998:1331) has emphasised that the Church was planned by God from eternity to eternity; it must retain God's vision for the world. Mission is at the very heart of the gospel and the life of the Church. Mission is not merely one of the many tasks that the Church is called upon to undertake, however: it is the very essence of the Church itself. And, of course, in order to communicate the gospel meaningfully and to serve effectively as God's prophetic agent in calling for the conversion and transformation of people, societies and cultures, the Church must know the socio-cultural and historical contexts in which it lives and ministers (Van Engen 1996:11). Mission does not merely focus on those who are sent; those who serve as senders are equally significant (Pirolo 1991:14).

Barth (Bosch 1995:32) has argued that '[m]ission refers to a permanent and intrinsic dimension of the church's life. The church is missionary by its very nature. God is a missionary God, God's people are missionary people. The church's mission is not secondary to its being; the church exists in being sent and in building up itself [sic] for its mission.'

This understanding of missions continually motivates them to be involved in world missions. Korean churches therefore enjoy

TABLE 5

Ministries in which missionaries should not be involved

\begin{tabular}{lccccc}
\hline & $\begin{array}{c}\text { All } \\
\text { ministries } \\
\text { are OK }\end{array}$ & $\begin{array}{c}\text { Church } \\
\text { planting }\end{array}$ & $\begin{array}{c}\text { Bible } \\
\text { school }\end{array}$ & Discipleship & No answer \\
\hline Number & 5 & 1 & 1 & 1 & 11 \\
Percentage & $26.31 \%$ & $5.26 \%$ & $5.26 \%$ & $5.26 \%$ & $57.89 \%$ \\
\hline
\end{tabular}

a rich heritage in missions. In 1912, the early Korean Church sent Ki-Poong Lee, one of seven ordained pastors, to Jeju Island. This occurred after Western missionaries had been ministering in Korea for only 20 years. From that time onwards, Korean churches have been carrying out the Great Commission by sending their missionaries and supporting them financially as well as with prayer and encouragement. Over the past two decades, Korean churches have sent more than 25000 missionaries to countries all over the world.

Korean churches expect to see their endeavours bear fruit as soon as their missionaries are sent out because their reports influence church members and encourage them to continue their interest in and support of the missions. Even before a new missionary has had time to adapt to a new culture or learn the language, their sending church is already asking, 'Have you started a church yet? How many people are attending your church? How many people have you baptised?' When missionaries are the recipients of these questions, they feel pressurised to begin their ministry and to submit a positive report to their church. There thus seems to be a misunderstanding in Korea of the processes involved in starting up a ministry in a new culture.

\section{Missionaries and their families}

Korean missionaries must maintain a proper balance between family and ministry. When they arrive in the mission field, they face, on the one hand, many difficulties, such as language barriers, foreign food, harsh weather conditions, foreign people and customs, and unfamiliar social mechanisms. On the other hand, missionary families spend a great deal of their time together in adjusting to a new host mission field. They should try to overcome all their difficulties jointly; this, however, takes time. After their adjustment to the field, they should maintain their family relationships by continuing to grow spiritually and upholding their ministry faithfully.

In research carried out by the Missions Commission of the World Evangelical Fellowship as part of its Reducing Missionary Attrition Project (ReMAP), 26 specific reasons for leaving missionary service were investigated (Taylor 1997:251). According to this study, $22.50 \%$ of attrition concerned family problems, such as health difficulties, children's needs, personal concerns, outside marriage (that is, marriage to a local person), elderly parents and marriage or family conflict. The attrition rate provides insight into how to anticipate and prevent difficulties in the field for Korean missionaries.

\section{What personal problems do Korean missionaries face?}

According to my research, $22.44 \%$ of the missionaries cited problems with maintaining their spiritual life and $0 \%$ felt that they lacked training. Financial concerns were a problem for $8.16 \%$ of the missionaries, while $30.61 \%$ mentioned family concerns, $4.08 \%$ cited health problems and $18.36 \%$ felt frustrated and unfulfilled. According to the results of my research, none of the Korean missionaries lacked training. Ironically, however, 38.77\% of the Korean missionaries responded that they encountered difficulties because of a lack of training.

This meant that they felt they needed retraining programmes in the field. There are many mission organisations, Bible colleges and seminaries that have, in fact, developed missionary retraining programmes, such as the Asian Cross- 
TABLE 6

Most important personal problems faced by Korean missionaries

\begin{tabular}{|c|c|c|c|c|c|c|c|c|}
\hline & $\begin{array}{l}\text { SPIRITUAL } \\
\text { LIFE OF THE } \\
\text { MISSIONARY }\end{array}$ & $\begin{array}{l}\text { LACK OF } \\
\text { TRAINING }\end{array}$ & $\begin{array}{l}\text { FINANCIAL } \\
\text { CONCERNS }\end{array}$ & $\begin{array}{r}\text { FAMILY } \\
\text { CONCERNS }\end{array}$ & $\begin{array}{r}\text { HEALTH } \\
\text { PROBLEMS }\end{array}$ & $\begin{array}{r}\text { SENSE OF } \\
\text { FULFILMENT/ } \\
\text { FRUSTRATION }\end{array}$ & NO PROBLEM & NO ANSWER \\
\hline $\mathrm{N}$ & 11 & 0 & 4 & 15 & 2 & 9 & 3 & 5 \\
\hline $\mathrm{P}$ & $22.44 \%$ & $0.00 \%$ & $8.16 \%$ & $30.61 \%$ & $4.08 \%$ & $18.36 \%$ & $6.12 \%$ & $10.20 \%$ \\
\hline
\end{tabular}

Cultural Theological Seminary, the Korea Research Institute for Missions, Chongshin University, the Tentmaking Support Centre and the GMS in Korea.

\section{CONCLUSION: WHERE THERE IS A WILL, THERE IS A WAY!}

A global mindset requires learning across cultural and national boundaries. Korean missionaries consequently need understanding and encouragement from Christian brothers and sisters of other countries. A global mentality calls for working together and overcoming cultural limitations and organisational boundaries. These missionaries need friends and partners in order to be the best practitioners of missions in the 21st century. A global outlook points to the promises and possibilities of mission innovation through advances in information communications technology. Korean missionaries desire a unified venture into future missions as part of God's multinational, multicultural and multilingual teams (Moon 2007:1).

I now conclude this article with six points.

Firstly, according to my research, it seemed that more than $60 \%$ of the Korean missionaries positively understood the context of the country in which they were serving. Even though they grew up in a monoculture, they tried to adapt to and understand the new culture. They were, in fact, still in the process of doing so. They were, however, experiencing difficulties in adjusting to a culture that, for example, had a different concept of time.

Secondly, in my research, I established that the Korean missionaries'language acquisition was solid. Inmy questionnaire, I did not, however, make a distinction between English and the local language. If I had asked more detailed questions, the result might have been different. If the Korean missionaries wanted to work more effectively in the field, learning the local language would be one of the basic tasks.

Thirdly, the Korean missionaries had adapted very positively to local culture. They had made an effort to adapt to their host culture while serving in missions. They did, however, experience difficulties in adapting to cultural differences not geared to keeping time, promises or schedules. They also found it difficult to adjust to local food.

In a presentation at a GMS Mission Forum (from 10 to 13 July 2006), the Rev. Cho, one of the leaders of the Korean missionary movement, stated the following:

A Korean person is not accustomed to learning another difficult language and culture. So the disadvantages of the Korean missionaries are that they have a weak cross-cultural adaptation and do not build good relationships with other foreign missionaries.

Korean missionaries must therefore overcome both language and culture barriers to attain a deep understanding of a culture, communicate effectively and establish sound relationships with others.

Fourthly, local people expected the Korean missionaries to be involved in the following areas of ministry: leadership or discipleship development, charitable ministry, church planting, Bible school, children's ministry and youth ministry. The Korean missionaries also, however, experienced that local people expected much financial support. Korean missionaries must
TABLE 7

TABLE 7
Most important professional problems faced by Korean missionaries

\begin{tabular}{llrr}
\hline & & NUMBERS & PERCENTAGE \\
\hline 1 & Spiritual exhaustion & 32 & $65.30 \%$ \\
2 & Little time for prayer & 24 & $48.97 \%$ \\
3 & Lack of training & 19 & $38.77 \%$ \\
4 & Financial problems & 20 & $40.81 \%$ \\
5 & Family problems & 9 & $18.36 \%$ \\
6 & Health problems & 24 & $48.97 \%$ \\
7 & Frustration: little sense of fulfilment & 14 & $28.57 \%$ \\
8 & Relationships & 5 & $10.20 \%$ \\
9 & Language & 6 & $12.24 \%$ \\
10 & Children's education & 1 & $2.04 \%$ \\
11 & Teamwork & 1 & $2.04 \%$ \\
12 & Misunderstanding of cultural differences & 1 & $2.04 \%$ \\
13 & Visa & 1 & $2.04 \%$ \\
14 & No answer & 2 & $4.08 \%$ \\
\hline & & & \\
\hline
\end{tabular}

know what local people want and need before they begin their ministry in the field. Above all, they must undertake research for an extensive period.

Fifthly, Korean missionaries must build very close relationships with their sending churches and supporters. They must also be thoroughly acquainted with the expectations of their sending churches. Churches that send their missionaries into mission fields want to hear what they are doing, what their difficulties are and what their host mission field looks like.

Sixthly and finally, as I infer from the tables, the most important personal problems of the Korean missionaries were family concerns, the maintenance of their spiritual life, health problems, financial concerns, frustration and unfulfilled ideals.

Mission is primarily and ultimately the work of the Triune God, Creator, Redeemer and Sanctifier for the sake of the world. It is a ministry in which the Church is privileged to participate. Mission has its origin in the heart of God, who is a fountain of sending love. This is the deepest source of mission (Bosch, 1991:392). Korean churches have been - and still are - involved in God's Great Commission. Mission programmes in these churches will continue until the second coming of Jesus our Lord. The title of the book by Van Engen (1996) - Mission is on the way - is the motto that Korean churches exemplify in a tangible manner. Korean missionaries in Southern Africa have a unique opportunity to serve the Church in its mission and above all - to serve the Lord of the Church in His mission. There are indeed difficulties to overcome and challenges to face. But, as my research underlines: Where there is a will, there is a way!

\section{REFERENCES}

Anderson, D., 1994, We felt like grasshoppers, Crossway Books, Nottingham.

Beals, P.A., 1985, A people for His name: A church-based missions strategy, William Carey Library, Pasadena.

Bosch, D.J., 1991, Transforming Mission: Paradigm Shift in Theology of Mission, Oribis, New York.

Bosch, D.J., 1995, Believing in the future: Toward a missiology of Western culture, Trinity Press International, Valley Forge.

Johnstone, P., 1998, The church is bigger than you think: The unfinished work of world evangelisation, WEC International, London. 
Johnstone, P. \& Mandryk, J., 2001, Operation world 21st century edition, WEC International, London.

Kritzinger, J.J., 1988, The South African context for mission, Lux Verbi, Cape Town.

Kritzinger, J.J., Meiring, P.G.J. \& Saayman, W.A., 1994, On being witness, Orion, Johannesburg.

Lloyd-Sidle, P. \& Lewis, B.S., 2001, Teaching mission in a global context, Geneva Press, Louisville.

Moon, S-C., 2007, The Protestant missionary movement in Korea: Current growth and development, viewed 22 April 2008, from http://krim.org/2007/sub3-crc.html.

Moreau, A.S. (ed.), 2000, Evangelical dictionary of world missions, Baker Books, Grand Rapids.
Neill, S., 1965, The pelican history of the church: A history of Christian missions, Penguin Books, London.

Pirolo, N., 1991, Serving as senders, OM International, San Diego.

Taylor, W.D. (ed.), 2000, Globalization of Mission Series: Global Missiology For The $21^{\text {st }}$ Century: The Iguassue Diologue, Baker Academic, Grand Rapids.

Tucker, R.A., 1983, From Jerusalem to Irian Jaya, Zondervan, Grand Rapids.

Van Engen, C., 1996, Mission is on the way, Baker Books, Grand Rapids. 